Check for updates

Cite this: RSC Adv., 2017, 7, 54196

Received 22nd October 2017

Accepted 12th November 2017

DOI: 10.1039/c7ra11657h

rsc.li/rsc-advances

\section{Purification and identification of antioxidative peptides of palm kernel expeller glutelin-1 hydrolysates}

\begin{abstract}
Yajun Zheng, $\mathbb{D} \dagger^{* a}$ Yan $\mathrm{Li}^{\mathrm{a}}$ and Yufeng Zhang ${ }^{\mathrm{b}}$
To obtain hydrolysates with high antioxidant activity and hydrolysis degree, palm kernel expeller glutelin-1 was hydrolyzed by pepsin assisted with high pressure pretreatment. The results of orthogonal experiment revealed that the optimum enzymatic hydrolysis conditions were as follows: enzymes concentration of $2 \mathrm{~g} /$ $100 \mathrm{~g}$, hydrolysis time of $4 \mathrm{~h}$, temperature $37^{\circ} \mathrm{C}$ and $\mathrm{pH}$ 2.0. Palm kernel expeller glutelin-1 hydrolysate was separated by ultrafiltration, Sephadex G-15 gel chromatography and reversed-phase high performance liquid chromatography. Finally, four peptides Thr-Val-Phe-Asp-Gly-Glu-Leu-Arg (935.5 Da), Ala-Asp-ValPhe-Asn-Pro-Arg (818.7 Da), Cys-Ala-Gly-Val-Ser-Ala-Ile-Arg (832.4 Da) and Leu-Val-Tyr-Ile-Ile-GlnGly-Arg (819.4 Da) were identified and their $\mathrm{IC}_{50}$ values on hydroxyl radical scavenging activities were $38.22 \pm 2.22,22.16 \pm 1.22,31.19 \pm 1.67$ and $12.85 \pm 0.23 \mu \mathrm{g} \mathrm{mL}^{-1}$, respectively. Furthermore, these peptides were chemically synthesized and the peptides ADVFNPR and CAGVSAIR showed good stability against simulated gastrointestinal protease digestion.
\end{abstract}

\section{Introduction}

Recently, increasing epidemiological evidence have indicated that excessive free radicals and associated oxidative damage are mediators in some chronic diseases, such as diabetes mellitus, neurodegenerative diseases and cardiovascular diseases. ${ }^{1}$ Antioxidants play a vital role in both food systems as well as in the human body to reduce oxidative stress. Since the use of synthetic antioxidants has been suspected to threaten human health, antioxidants from natural sources have attracted increasing attention. Without marked adverse effects on the human body, peptides derived from various food proteins have been accepted as a new source of natural antioxidants. Some antioxidant peptides have been identified from varieties of food proteins such as soy protein, walnut protein, rice bran protein, potato protein and fish proteins..$^{2-6}$ Except for the isolation and characterization, the in vivo physiological effects, structureactivity relationship and mechanism of action of some antioxidant peptides as well as their stability to processing and storage conditions used in food industry have been studied. ${ }^{7}$

Palm kernel expeller (PKE) is the main byproduct of palm milling industry, which contains about $20 \%$ protein. $^{8}$ Palm kernel expeller protein (PKP) is a good potential edible protein due to its relatively well-balanced amino acid profile, good

${ }^{a}$ Institute of Food Science of Shanxi Normal University, Linfen, 041004, China. E-mail: zyj_coconut@163.com; Fax: +86-0357-2051482; Tel: +86-13976563642

${ }^{b}$ Coconut Research Institute of Chinese Academy of Tropical Agriculture Sciences, Wenchang, 571339, China

$\dagger$ The two authors contribute equally to this work and they are co-first author. solubility and emulsifying capacity. ${ }^{9}$ Globulin, glutelin-1 and glutelin-2 accounted for $40.10 \%, 24.01 \%$ and $33.32 \%$ of PKP, respectively. ${ }^{10}$ It was found that enzymatic hydrolysates of the globulin showed anticancer, antihypertensive and antibacterial activities; also several peptides obtained from the glutelin-2 could effectively lower the systolic blood pressure of spontaneously hypertensive rats. ${ }^{11-13}$ Dilute acid-soluble seed storage proteins are commonly known as glutelin-1 proteins. ${ }^{14} \mathrm{~A}$ previous study has demonstrated that palm kernel expeller glutelin-1 (PKEG-1) exhibited high scavenging activity of DPPH radical $(77.69 \%)$, ABTS radical $(64.19 \%)$, superoxide radical $(49.54 \%)$ and hydroxyl radical (34.41\%); also it exhibited high reducing power $(0.211 \pm 0.009),{ }^{10}$ indicating that antioxidant peptides could be isolated from it. However, no study on the purification and identification of antioxidant peptides from PKEG-1 is available. In addition, nearly 2.5 million tons of PKE are produced per year in Malaysia alone ${ }^{15}$ prompting efforts to explore it for value-addition products such as bioactive peptides.

In the current study, the optimal enzymatic hydrolysis condition of PKEG-1 was investigated and antioxidant peptide fractions were isolated by ultrafiltration membranes, Sephadex G-15 chromatography and reverse phase high performance liquid chromatography (RP-HPLC). The amino acid sequences of the individual antioxidant peptides were subsequently identified using capillary liquid chromatography/electrospray ionization/mass spectrometry/mass spectrometry (LC-MS/MS); in addition, the stability of antioxidant peptides against gastro-intestinal digestion was studied. 


\section{Materials and methods}

\subsection{Materials and reagents}

Oil palm kernel expeller (PKE) was obtained from the Meiye Food Processing Co. Ltd., China. Pepsin $\left(5 \times 10^{4} \mathrm{U} \mathrm{g}^{-1}\right)$ was purchased from Shanghai Biotech. Co., Ltd. (China). Sephadex G-15 was purchased from Pharmacia (Uppsala, Sweden). ABTS (2,2'-azino-bis(3-ethylbenzothiazoline-6-sulphonic acid)) and other reagents were of analytical grade.

\subsection{Preparation of palm kernel expeller glutelin-1 (PKEG-1)}

PKE was defatted three times with $n$-hexane $\left(1: 10, \mathrm{~g} \mathrm{~mL}^{-1}\right)$, and then dried, ground and passed through a sieve of $0.2 \mathrm{~mm}$ mesh. Then, $30 \mathrm{~g}$ of defatted PKE was suspended in $300 \mathrm{~mL}$ of $0.4 \mathrm{M} \mathrm{NaCl}$, stirred at $4{ }^{\circ} \mathrm{C}$ for $1 \mathrm{~h}$ and filtered. The residue was collected and again suspended in $0.4 \mathrm{M} \mathrm{NaCl}$ and stirred at $4{ }^{\circ} \mathrm{C}$ for $1 \mathrm{~h}$. This step was repeated in triplicate to remove PKE albumin and globulin. Then, the residue was suspended in 50\% $(\mathrm{v} / \mathrm{v})$ glacial acetic acid $\left(1: 10, \mathrm{~g} \mathrm{~mL}^{-1}\right)$. After being stirred at $4{ }^{\circ} \mathrm{C}$ for $1 \mathrm{~h}$, the mixture was centrifuged at $10000 \mathrm{~g}$ for $30 \mathrm{~min}$. The supernatant was dialyzed against distilled water at $4{ }^{\circ} \mathrm{C}$ for $48 \mathrm{~h}$, and then lyophilized. Subsequently, PKEG-1 was obtained and stored at $-20{ }^{\circ} \mathrm{C}$.

\subsection{Optimization of the enzymatic hydrolysis}

Initially, $2 \mathrm{~g}$ of PKEG-1 was rehydrated in $100 \mathrm{~mL}$ of acetate buffer (0.1 M, pH 2.0) and subjected to high pressure (HP) treatment following the method outlined by Zheng et al. ${ }^{13} \mathrm{HP}$ treatment was performed by a HPP-L3 high-pressure apparatus (Tianjin HuaTaiSenMiao Biotechnology Co. Ltd., China) at $300 \mathrm{MPa}$ and $35^{\circ} \mathrm{C}$, for $20 \mathrm{~min}$. As PKEG-1 is an acid-soluble protein, pepsin was chosen to hydrolyze it. An orthogonal $\mathrm{L}_{9}$ $\left(4^{3}\right)$ test design with hydroxyl radical scavenging activity (SA) as response was used to investigate the optimal hydrolysis conditions of pepsin. Four controllable variables with three levels, including enzyme-to-substrate ratio $(\mathrm{E} / \mathrm{S})$, hydrolysis time, temperature and $\mathrm{pH}$ were selected for optimization (Table 1).

Further, PKEG-1, treated with HP, was hydrolyzed by pepsin under the obtained optimum conditions. After digestion, the solutions were deactivated in boiling water for $10 \mathrm{~min}$ and centrifuged at $10000 \mathrm{~g}$ for $20 \mathrm{~min}$. The supernatant was collected, and lyophilized to obtain PKEG-1 hydrolysates (PKEG-1H). The hydrolysis degree (DH) and scavenging activity on hydroxyl radical

Table 1 Experimental values and levels of the independent variables for the $L_{9}\left(4^{3}\right)$ orthogonal experiment

\begin{tabular}{llrr}
\hline & \multicolumn{2}{l}{ Levels } & \\
\cline { 2 - 4 } Independent variable & 1 & \multicolumn{1}{c}{3} \\
\hline$A$ E/S $(\mathrm{g} / 100$ g protein $)$ & 1 & 1.5 & 2.0 \\
$B$ hydrolysis time $(\mathrm{h})$ & 2.0 & 3.0 & 4.0 \\
$C$ temperature $\left({ }^{\circ} \mathrm{C}\right)$ & 32.0 & 37.0 & 42.0 \\
$D \mathrm{pH}$ & 2.0 & 3.0 & 4.0
\end{tabular}

$\left({ }^{\circ} \mathrm{OH}\right)$ were determined by the Adler-Nissen method ${ }^{\mathbf{1 6}}$ and the 2deoxyribose oxidation method, ${ }^{17}$ respectively.

\subsection{Separation by ultrafiltration and Sephadex G-15 gel chromatography}

The PKEG-1 hydrolysates (PKEG-1H) prepared, by pepsin assisted with HP, was filtered sequentially using an ultrafiltration unit (Pellicon XL, Millipore, USA) through two ultrafiltration membranes with molecular weight (MW) cut-offs of 5 and 3 kDa, respectively. Three fractions were obtained: PKEG-1H-I with MW > 5 kDa, PKEG-1H-II with MW 3-5 kDa and PKEG$1 \mathrm{H}-\mathrm{III}$ with $\mathrm{MW}<3 \mathrm{kDa}$. The fraction with the highest antioxidant activity was further separated by a Sephadex G-15 gel filtration column $(\Phi 1.6 \mathrm{~cm} \times 100 \mathrm{~cm})$, eluted with distilled

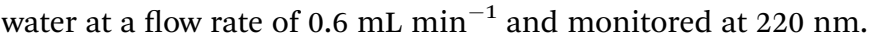
Fractions were collected, lyophilized and stored at $-20{ }^{\circ} \mathrm{C}$.

\subsection{Antioxidant activity of PKEG-1H fractions}

2.5.1 Superoxide radical-scavenging activity. Superoxide radical-scavenging activity was measured using the pyrogallol assay as described by Qiao et al. ${ }^{17}$ Briefly, $0.1 \mathrm{~mL}$ of sample solution was mixed with $3 \mathrm{~mL}$ of pyrogallol solution ( $3 \mathrm{mM}$ ); the absorbance at $320 \mathrm{~nm}$ was recorded at $30 \mathrm{~s}$ intervals. The scavenging activity was calculated from the absorbance at $320 \mathrm{~nm}$ in the presence or absence of samples. Glutathione (GSH) was used for comparison.

2.5.2 Scavenging activity of hydroxyl radical. Following the method reported by Qiao et al.,$^{17}$ the reaction mixture contained sample solution $\left(100 \mu \mathrm{g} \mathrm{mL} \mathrm{m}^{-1}\right), \mathrm{FeSO}_{4}$-EDTA (10 mM), 2deoxyribose $(10 \mathrm{mM})$, phosphate buffer $(\mathrm{pH} 7.4,0.1 \mathrm{M})$ and $\mathrm{H}_{2} \mathrm{O}_{2}(10 \mathrm{mM})$. After being incubated at $37{ }^{\circ} \mathrm{C}$ for $1 \mathrm{~h}$, the reaction solution was mixed with trichloroacetic acid $\left(28 \mathrm{mg} \mathrm{mL}^{-1}\right)$ and thiobarbituric acid $\left(10 \mathrm{mg} \mathrm{mL}^{-1}\right)$, and then incubated at $100{ }^{\circ} \mathrm{C}$ for $20 \mathrm{~min}$. The absorbance was measured at $532 \mathrm{~nm}$. GSH was used as the comparison. The activity was determined as follows:

$$
\text { OH scavenging activity }(\%)=\left[1-\left(A_{\mathrm{S}}-A_{\mathrm{B}}\right) / A_{\mathrm{C}}\right] \times 100
$$

where $A_{\mathrm{B}}$ is the absorbance of the blank (distilled water instead of samples), $A_{\mathrm{C}}$ is the absorbance of control (without the addition of 2-deoxyribose oxidation) and $A_{\mathrm{S}}$ is the absorbance of mixture contained samples.

2.5.3 ABTS radical scavenging ability. According to the TEAC assay, ${ }^{18} 20 \mu \mathrm{L}$ of protein solution $\left(0.1-0.5 \mathrm{mg} \mathrm{mL}^{-1}\right)$ was mixed with $2 \mathrm{~mL}$ of ABTS solution, and then kept in the dark at $30{ }^{\circ} \mathrm{C}$ for $6 \mathrm{~min}$. Then, absorbance at $734 \mathrm{~nm}$ was recorded. GSH was used for comparison. The activity was calculated as follows:

$$
\text { Scavenging activity }(\%)=\left[1-\left(A_{\mathrm{S}}-A_{\mathrm{B}}\right) / A_{\mathrm{C}}\right] \times 100
$$

where $A_{\mathrm{C}}$ is the absorbance of control (distilled water instead of $\mathrm{ABTS}^{+}$solution).

2.5.4 Ferrous ion chelating capacity. Following the method reported by Joshi et al., ${ }^{18} 450 \mu \mathrm{L}$ sample solutions (0.1-0.5 mg mL ${ }^{-1}$ ) were mixed with $45 \mu \mathrm{L} \mathrm{FeCl}_{2}(2 \mathrm{mM})$ and $1815 \mu \mathrm{L}$ of distilled water. Then, $90 \mu \mathrm{L}$ ferrozine $(5 \mathrm{mM})$ was 
added to start the reaction and the absorbance at $562 \mathrm{~nm}$ was read after $30 \mathrm{~min}$. Chelating activity was calculated as follows:

$$
\text { Chelating activity }(\%)=\left[1-\left(A_{\mathrm{S}}-A_{\mathrm{B}}\right) / A_{\mathrm{C}}\right] \times 100
$$

where $A_{\mathrm{C}}$ is the absorbance of control (without the addition of ferrozine).

\subsection{Purification of the antioxidant peptides}

The PKEG-1H fraction showing the highest antioxidant activity after the Sephadex G-15 chromatography was separated by RPHPLC on a Zorbax semi-preparative $\mathrm{C}_{18}$ column $(\Phi 9.4 \mathrm{~mm} \times$ $250 \mathrm{~mm}$, Agilent Technologies, USA), using a linear gradient of acetonitrile containing $0.1 \%$ TFA $(5-30 \%, 30 \mathrm{~min})$ at a flow rate of $2.5 \mathrm{~mL} \mathrm{~min}^{-1}$. The fraction showing high antioxidant activity was further isolated on a Zorbax analysis $\mathrm{C}_{18}$ column $(\Phi 4.6 \mathrm{~mm}$ $\times 250 \mathrm{~mm}$, Agilent Technologies, USA) with a linear gradient of acetonitrile containing $0.1 \%$ TFA (5-25\%, in $20 \mathrm{~min}$ ) at a flow

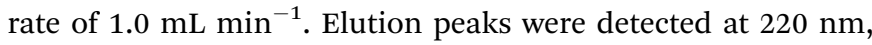
concentrated, and lyophilized.

\subsection{Molecular mass and amino acid sequence of the purified peptides}

To identify molecular mass and accurate amino acid sequence of the purified peptides from RP-HPLC, the peptides were determined by LC-MS/MS coupled with a Eksigent Nano LC (Eksigent Technologies, Dublin, CA, USA) and Thermo LTQ linear ion trap mass spectrometer (Thermo Fisher, San Jose, CA, USA). The peptide sequences were matched to the published sequences of Elaeis guineensis proteins from the National Center for Biotechnology Information (NCBI, Bethesda, MD, USA) database.

\subsection{Peptide synthesis}

Following the solid phase procedure described by Zhang et al., ${ }^{5}$ antioxidant peptides identified from PKEG-1H were synthesized with a Kromasil 100-5 $\mathrm{C}_{18}$ column $(\Phi 4.6 \times 250 \mathrm{~mm}$, particle size $5 \mu \mathrm{m})$. The synthetic peptides were confirmed by Liquid Chromatography coupled to Mass Spectrometry (LC-MS/ESI), and their purity was more than $95 \%$.

\subsection{Stability of the synthetic peptides}

The synthetic peptides $\left(1 \mathrm{mg} \mathrm{mL} \mathrm{m}^{-1}\right)$ were successively digested by $\operatorname{pepsin}(\mathrm{E} / \mathrm{S}=1: 35)$ and pancreatin $(\mathrm{E} / \mathrm{S}=1: 25)$ as described by Tavares et al. ${ }^{19}$ The ${ }^{\circ} \mathrm{OH}$ scavenging of the treated synthetic peptides was determined, and the untreated synthetic peptides were used for comparison.

\subsection{Statistical analysis}

All the results were the means of triplicates. Data were subjected to analysis of variance and Duncan test with a confidence interval of $95 \%$.

\section{Results and discussion}

\subsection{Optimization of hydrolysis conditions}

The results of the orthogonal test are summarized in Table 2. It was revealed that the influential extent of the four factors to ${ }^{\circ} \mathrm{OH}$ scavenging activity of PKEG-1 was: $A(\mathrm{E} / \mathrm{S})>C$ (temperature $)>B$ (hydrolysis time) $>D(\mathrm{pH})$; both $\mathrm{E} / \mathrm{S}$ and temperature had significant effect on the ${ }^{\circ} \mathrm{OH}$ scavenging activity $(P<0.05)$. The best level of these factors was $A 3 B 3 C 2 D 1$, suggesting that the highest ${ }^{\circ} \mathrm{OH}$ scavenging activity $(89.14 \% \pm 4.84 \%)$ of PKEG-1 hydrolysates $\left(1 \mathrm{mg} \mathrm{mL}^{-1}\right)$ could be obtained when the

Table 2 The result and variance analysis of the $L_{9}\left(4^{3}\right)$ orthogonal experiment

\begin{tabular}{|c|c|c|c|c|c|c|}
\hline \multirow[b]{2}{*}{ No. } & \multirow{2}{*}{$\frac{A}{\mathrm{E} / \mathrm{S}(\%)}$} & \multirow{2}{*}{$\frac{B}{\text { Hydrolysis time }(\mathrm{h})}$} & \multirow{2}{*}{$\frac{C}{\text { Temperature }\left({ }^{\circ} \mathrm{C}\right)}$} & \multirow{2}{*}{$\frac{D}{\mathrm{pH}}$} & \multirow[b]{2}{*}{$\mathrm{SA}^{a}(\%)$} & \multirow[b]{2}{*}{$\mathrm{DH}^{b}(\%)$} \\
\hline & & & & & & \\
\hline 1 & 1 & 1 & 1 & 1 & $59.66 \pm 4.69$ & $15.92 \pm 0.68$ \\
\hline 2 & 1 & 2 & 2 & 2 & $68.19 \pm 2.97$ & $17.61 \pm 1.93$ \\
\hline 3 & 1 & 3 & 3 & 3 & $68.00 \pm 4.91$ & $18.02 \pm 0.89$ \\
\hline 4 & 2 & 1 & 2 & 3 & $75.94 \pm 8.14$ & $23.14 \pm 2.22$ \\
\hline 5 & 2 & 2 & 3 & 1 & $80.90 \pm 6.41$ & $25.77 \pm 1.28$ \\
\hline 6 & 2 & 3 & 1 & 2 & $74.55 \pm 5.22$ & $23.29 \pm 1.72$ \\
\hline 7 & 3 & 1 & 3 & 2 & $83.81 \pm 4.19$ & $27.11 \pm 2.37$ \\
\hline 8 & 3 & 2 & 1 & 3 & $77.01 \pm 6.37$ & $25.56 \pm 0.70$ \\
\hline 9 & 3 & 3 & 2 & 1 & $89.14 \pm 4.84$ & $31.90 \pm 2.72$ \\
\hline$K_{1}$ & 195.85 & 219.41 & 211.22 & 229.70 & & \\
\hline$K_{2}$ & 231.39 & 226.11 & 233.26 & 226.55 & & \\
\hline$K_{3}$ & 249.97 & 231.68 & 232.71 & 220.95 & & \\
\hline Best level & $\mathrm{A}_{3}$ & $\mathrm{~B}_{3}$ & $\mathrm{C}_{2}$ & $\mathrm{D}_{1}$ & & \\
\hline$R^{c}$ & 54.11 & 12.28 & 22.04 & 8.75 & & \\
\hline$R$ Order & $A>C>$ & & & & & \\
\hline$d_{\mathrm{f}}$ & 2 & 2 & 2 & 2 & & \\
\hline Sum of squares & 503.90 & 25.19 & 105.30 & 6.54 & & \\
\hline$F$ Value & $38.51^{d}$ & 1.92 & $8.05^{d}$ & 1 & $F_{0.05}=6.94$ & \\
\hline
\end{tabular}


a
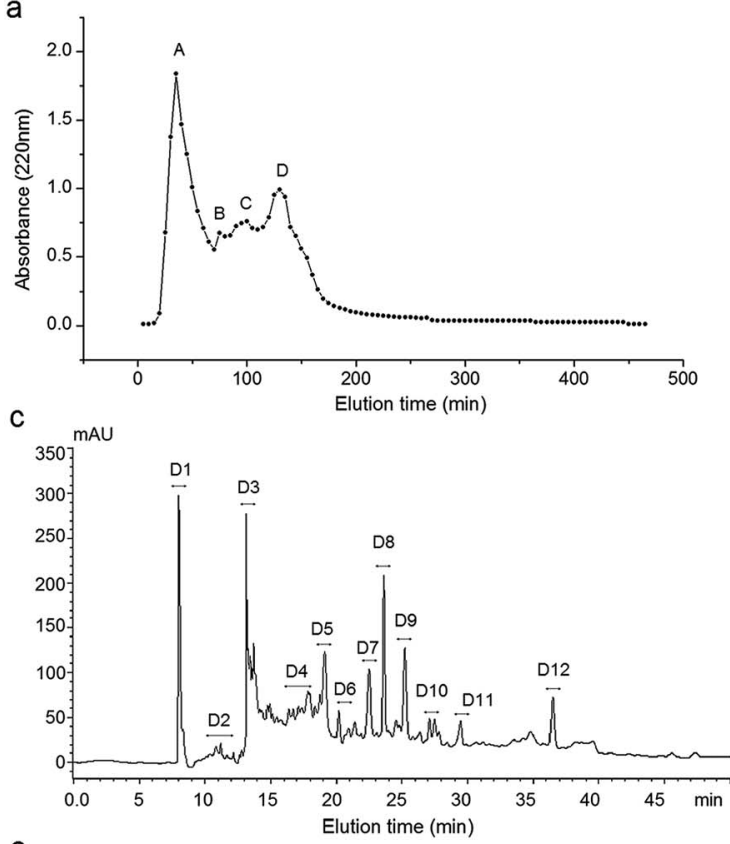

e

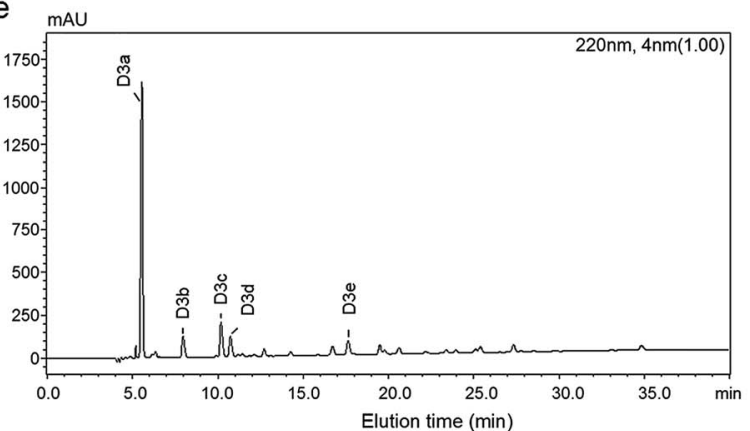

b

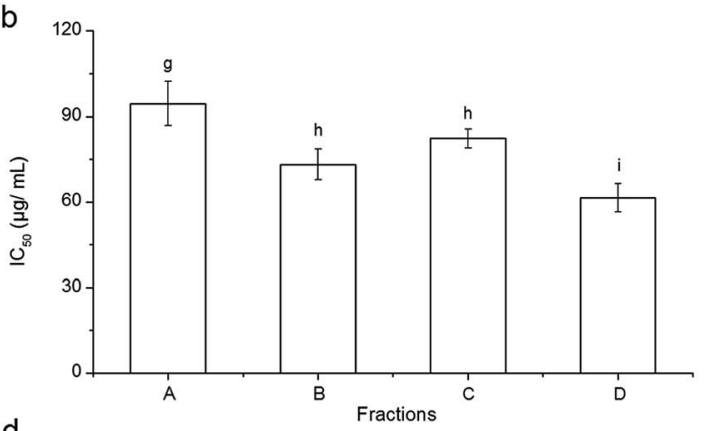

d
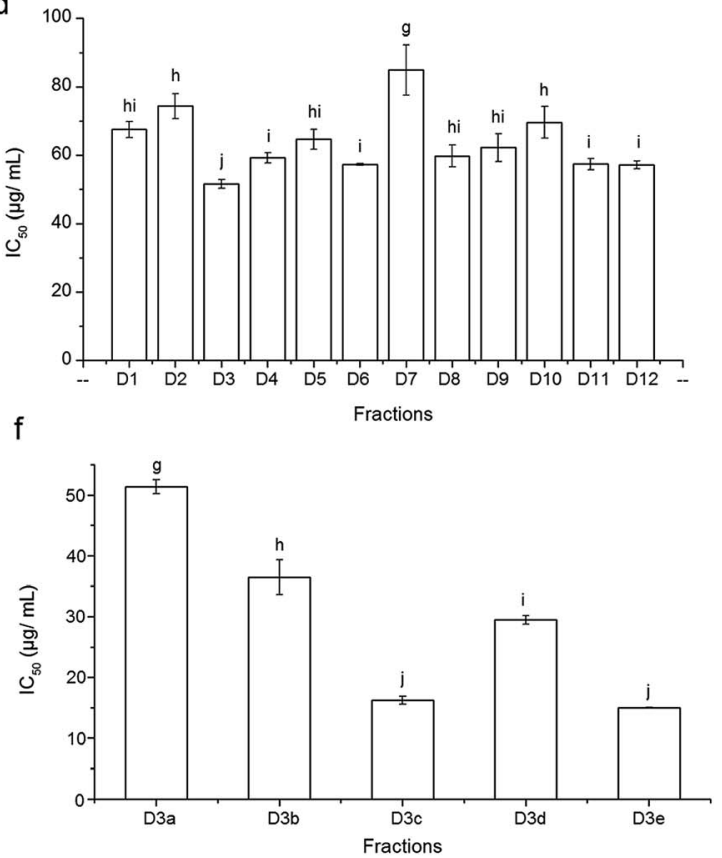

Fig. 1 Sephadex G-15 gel chromatography profile of PKEG-1H (a) and hydroxyl radical ( $\left.{ }^{\circ} \mathrm{OH}\right)$ scavenging activity of each fraction (b); chromatography of fraction $D$ separated by semi-preparing RP-HPLC (c); ${ }^{\circ} \mathrm{OH}$ scavenging activity of fractions D1-D12 (d); fraction D3 was separated by analytical RP-HPLC (e); ${ }^{\circ} \mathrm{OH}$ scavenging activity of fractions D3a to D3e (f); small letters $(\mathrm{g}-\mathrm{j})$ on the bars meant significant difference $(P<$ 0.05).

concentration of pepsin was $2 \mathrm{~g} / 100 \mathrm{~g}$ protein, $\mathrm{pH}$ was set at 2.0, and the hydrolysis time and temperature were $4.0 \mathrm{~h}$ and $37^{\circ} \mathrm{C}$, respectively. Consequently, the DH was $31.90 \% \pm 2.72 \%$, which was lower than that of palm kernel globulin (59\%) digested by pepsin and trypsin. ${ }^{12}$ PKE glutelin is an acid-soluble protein and difficult to dissolve at neutral $\mathrm{pH}$, which is suitable for trypsin. Thus, trypsin was not chosen in this study.

\subsection{Gel chromatography of PKEG-1H and antioxidant activity of the fractions}

3.2.1 Separation by ultrafiltration and Sephadex G-15 gel chromatography. Hydroxyl radical is accepted as the indicator for purification of antioxidant peptides because it is one of the most reactive radicals and can attack almost every living cell. ${ }^{7}$ Among the three fractions obtained after ultrafiltration, PKEG$1 \mathrm{H}-\mathrm{III}$ with the lowest molecular weight $\left(M_{\mathrm{w}}\right)$ exhibited the highest ${ }^{\circ} \mathrm{OH}$ scavenging activity $\left(\mathrm{IC}_{50}: 88.82 \pm 5.15 \mu \mathrm{g} \mathrm{mL}{ }^{-1}\right)$, hence it was chosen for gel chromatography analysis. As shown in Fig. 1a, four fractions (fraction $A, B, C$ and $D$ ) were collected separately after Sephadex G-15 gel chromatography. In gel chromatography, the separation is based on the $M_{\mathrm{w}}$, that is, peptides with large $M_{\mathrm{w}}$ are eluted earlier, while those with lower $M_{\mathrm{w}}$ are eluted later. Thus, the order of the $M_{\mathrm{w}}$ of the four peaks was $A>B>C>D$. Fraction $D$ showed the highest ${ }^{\circ} \mathrm{OH}$ scavenging activity $\left(\mathrm{IC}_{50}: 61.43 \pm 4.97 \mu \mathrm{g} \mathrm{mL} \mathrm{m}^{-1}\right.$, Fig. $\left.1 \mathrm{~b}\right)$ among the fractions, which was in accordance with the result shown in Fig. 2a. The results confirmed the report that short peptides exhibited stronger antioxidant activity than larger polypeptides. ${ }^{19}$

3.2.2 Antioxidant activity of fractions from Sephadex G-15 gel chromatography. Superoxide anion radical is a potential precursor of stronger reactive oxidative species such as hydroxyl radical. ${ }^{6}$ As shown in Fig. 2b, the superoxide radical scavenging activities of PKEG-1H fractions $(A-D)$ were all dependent on the concentration used. The fraction $D$ showed a higher activity $\left(\mathrm{IC}_{50}\right.$ : $\left.0.486 \mathrm{mg} \mathrm{mL}^{-1}\right)$ than fractions $A$ and $B(P<0.05)$, possibly due to the relatively lower $M_{\mathrm{w}} \cdot{ }^{5}$ The activity of fraction $D$ was also higher than that of loach protein hydrolysate $\left(\mathrm{IC}_{50}: 0.74 \mathrm{mg} \mathrm{mL}{ }^{-1}\right){ }^{6}$ indicating that fraction $D$ could contain peptides that are more 

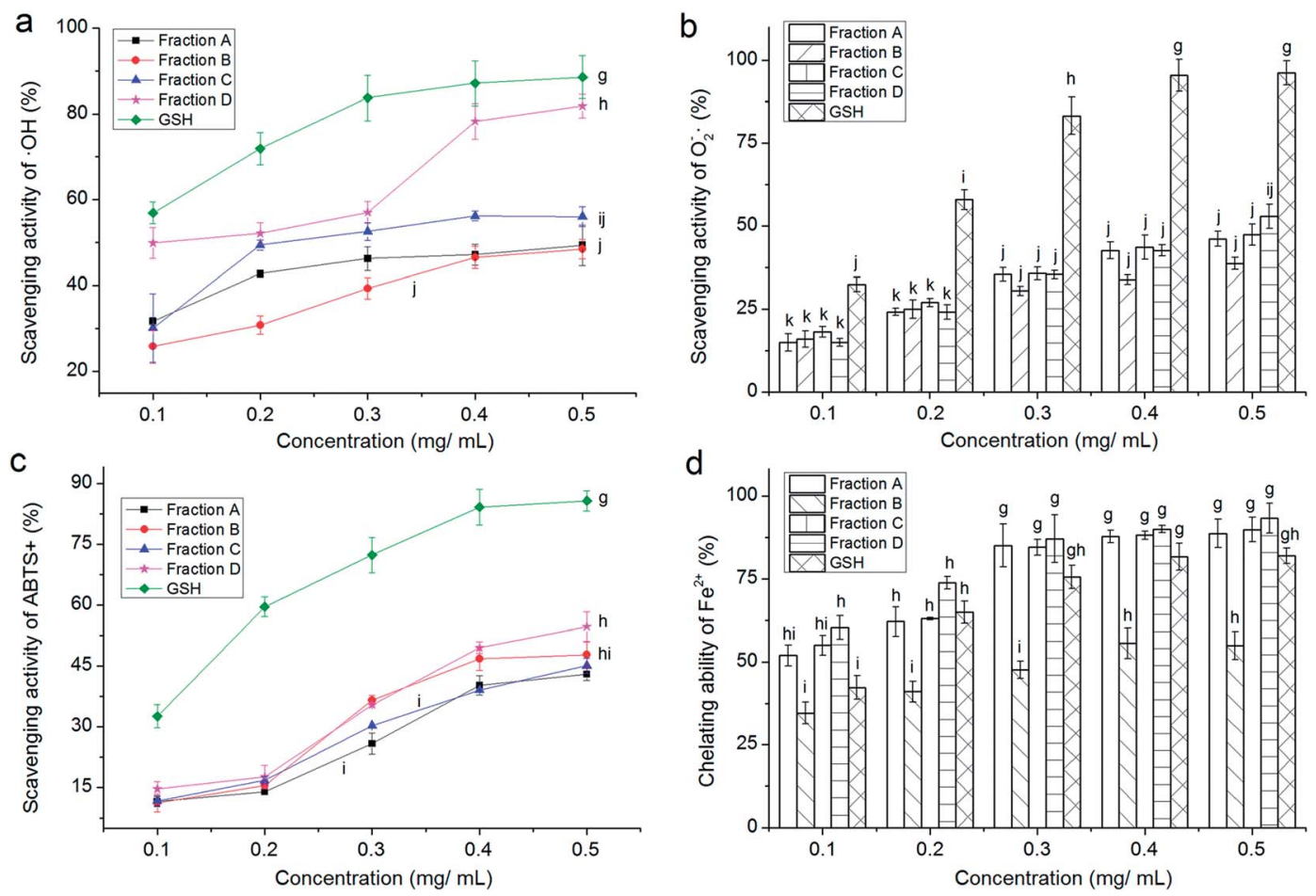

Fig. 2 Antioxidant activity of fractions $A-D$ including scavenging activity on hydroxyl radical (a), superoxide radical (b), ABTS radical (c) and chelating ability (d); GSH (glutathione) was used for comparison; small letters $(\mathrm{g}-\mathrm{k})$ on the bars or lines match results that are significantly different $(P<0.05)$.

easily accessible to the superoxide radical and allows these peptides to trap the radicals more easily. The ABTS radical scavenging activity was widely employed to estimate the total antioxidant activity of potential antioxidants. ${ }^{18}$ The results in Fig. 2c showed that all of the fractions exhibited considerable ABTS radical-scavenging activity at a concentration of $0.1-0.5 \mathrm{mg}$ $\mathrm{mL}^{-1}$, indicating their considerable total antioxidant activity. Fraction $D$ also showed remarkably higher activity than fractions $A$ and $B(P<0.05)$. Moreover, as shown in Fig. $2 \mathrm{~d}$, all the fractions except fraction $B$ exhibited significantly higher chelating capacity than GSH $(P<0.05)$. The chelating ability of fraction $D$ could reach up to $93.27 \% \pm 4.52 \%$, which was much higher than that of sweet potato protein hydrolysates $(17.62 \%)^{2}$ and sliver carp hydrolysates $(18.20 \%){ }^{5}$ A previous study had found that PKE glutelin-1 was rich in Glu and Asp, ${ }^{10}$ which could interact with metal ions through the charged groups and inactivate the prooxidant activity of metal ions..$^{20}$ In general, fraction $D$ was selected to further purification and characterization for its high antioxidant activity.

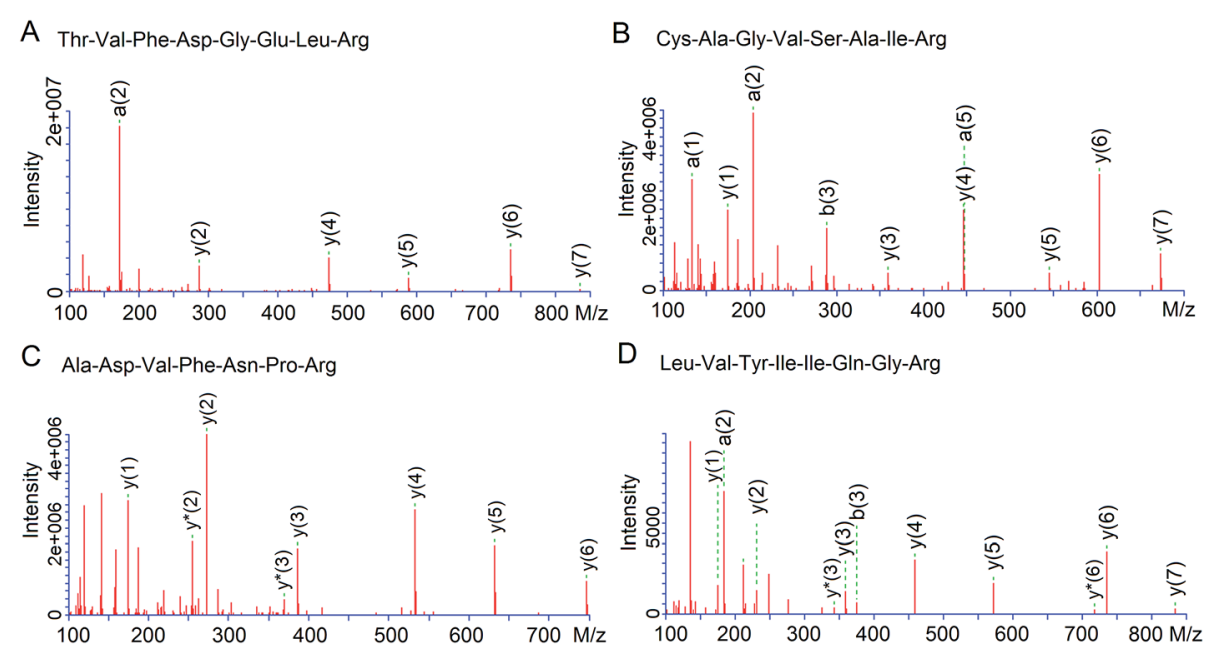

Fig. 3 Mass spectra of the RP-HPLC chromatograms fraction D3c and D3e by LC-MS/MS. 
Table 3 Antioxidant peptides identified in palm kernel expeller glutelin-1 by LC-MS/MS and their stability against the simulated gastrointestinal digestion $^{c}$

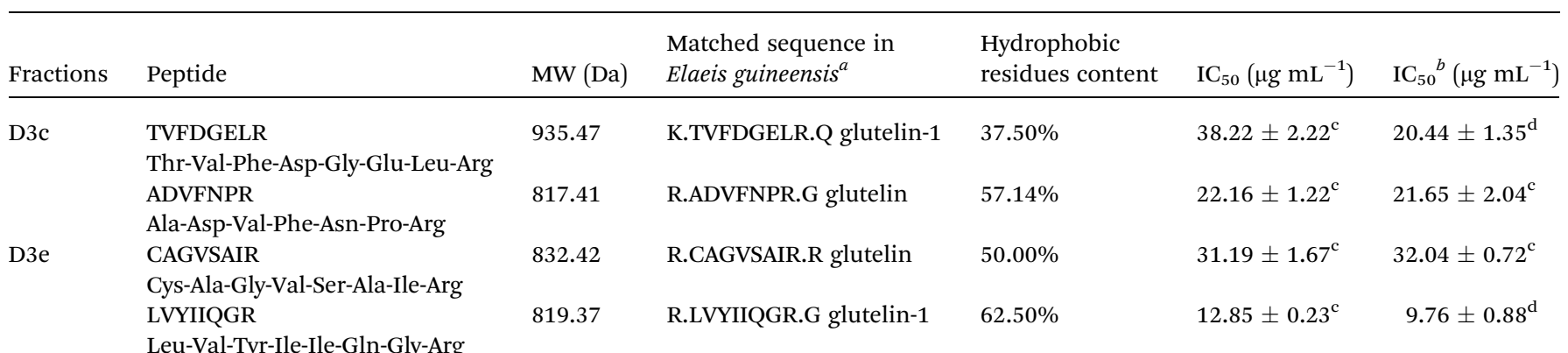

${ }^{a}$ From National Center for Biotechnology Information (NCBI). ${ }^{b}$ Peptides were treated with pepsin and pancreatin. ${ }^{c \text { c,d }}$ Different small letters in the same row indicates significant difference $(P<0.05)$.

\subsection{Purification of the antioxidant peptides}

Fraction $D$ from Sephadex G-15 gel chromatography was further isolated by RP-HPLC on the semi-preparative $\mathrm{C}_{18}$ column, and 12 major peaks named as D1-D12 were presented and collected (Fig. 1c). D3 with the lowest $\mathrm{IC}_{50}\left(51.57 \pm 1.26 \mu \mathrm{g} \mathrm{mL}{ }^{-1}\right.$, Fig. 1d) was further purified by RP-HPLC in an analytical $\mathrm{C}_{18}$ column $(\Phi 4.6 \mathrm{~mm} \times 250 \mathrm{~mm})$ and five major fractions (D3a-D3e) were obtained (Fig. 1e). The fraction D3c and D3e demonstrated significantly lower $\mathrm{IC}_{50}$ values $(16.22 \pm 0.64$ and $15.00 \pm 0.03 \mu \mathrm{g}$ $\mathrm{mL}^{-1}$, respectively, Fig. 1f) than other fractions $(P<0.05)$, and they were subjected to ESI-MS/MS analysis. In RP-HPLC, hydrophilic peptides were eluted earlier while the non-polar or hydrophobic peptides eluted much later. ${ }^{4}$ Moreover, it was evident that high content of hydrophobic amino acids could increase the antioxidant activity of peptides. ${ }^{21}$ The fraction D3e with high hydrophobicity exhibited the highest antioxidant activity in this study, which is in accordance with the previous reports.

\subsection{Characterization of purified peptides}

As shown in Fig. 3, four peptides were identified by LC-MS/MS, of which TVFDGELR (935.5 Da) and ADVFNPR (818.7 Da) was from fraction D3c, while CAGVSAIR (832.4 Da) and LVYIIQGR (819.4 Da) were from fraction D3e. The four peptides were all short peptides with 7-8 amino acids and exhibited relatively high antioxidant activity ( $\mathrm{IC}_{50}: 38.22-12.85 \mu \mathrm{g} \mathrm{mL} \mathrm{m}^{-1}$, Table 3 ), which was in accordance to the report that antioxidant activity of peptides was inversely correlated with $M_{\mathrm{w}} \cdot{ }^{19}$ However, both ADVFNPR and LVYIIQGR exhibited higher antioxidant activity than the smaller peptides from rice residue $\left(464.2 \mathrm{Da}, \mathrm{IC}_{50}\right.$ : $\left.43.55 \mu \mathrm{g} \mathrm{mL}^{-1}\right),{ }^{22}$ tilapia protein $\left(317.3 \mathrm{Da}, \mathrm{IC}_{50}: 26.4 \mu \mathrm{g} \mathrm{mL}^{-1}\right)^{6}$ and walnut protein $\left(423.23 \mathrm{Da}, \mathrm{IC}_{50}: 310.0 \mu \mathrm{g} \mathrm{mL}^{-1}\right),{ }^{3}$ indicating that antioxidant activity of peptides was not dependent only on $M_{\mathrm{w}}$. Moreover, Tapal et al. ${ }^{12}$ also obtained the peptide ADVFNPR from palm kernel globulin and found that it had antihypertensive and anticancer activity.

It was demonstrated that antioxidant activity of peptides is positively correlated with the hydrophobic property. ${ }^{21}$ The order of hydrophobic amino acid content for the four peptides was LVYIIQGR > ADVFNPR > CAGVSAIR > TVFDGELR (Table 3). With higher hydrophobicity, LVYIIQGR showed a higher antioxidant activity $\left(\mathrm{IC}_{50}: 12.85 \mu \mathrm{g} \mathrm{mL}^{-1}\right)$ than TVFDGELR and YPGSIDWR ( IC $_{50}$ : 31.19-38.22 $\mu \mathrm{g} \mathrm{mL}^{-1}$ ).

Moreover, it has been reported that the amino acid constituents and sequences play an important role in the antioxidant properties of peptides. ${ }^{22}$ Some amino acids such as Leu, Cys, His, Tyr, Met and Trp contributed significantly to the antioxidant activities of peptides. Leu could increase the presence of the peptides at the water-lipid interface and therefore facilitate access to scavenge free radicals generated at the lipid phase. ${ }^{23}$ Tyr, Trp and Phe possess phenolic groups that have special capability of to serve as hydrogen donors; Met tends to undergo oxidation to form Met sulphoxide and Cys donates the sulphur hydrogen; the imidazole group in His also exhibits protondonation ability. ${ }^{5,24}$ Hence, the high antioxidant activity of the four peptides identified in the current study was attributed to the presence of Leu, Cys, Phe, Tyr, Phe and Trp (Table 3). In addition, the branched amino acids (Leu, Val and Ile) in LVYIIQGR also contribute to the antioxidant activity. Other researchers have also found that peptides containing branched amino acid residues (HPLL, LLHH and HHPLL) had good antioxidant activity.,

\subsection{Stability of synthetic peptides}

As shown in Table 3, after digestion with pepsin and pancreatin, the antioxidant activity of synthetic peptides, CAGVSAIR and ADVFNPR, was not significantly decreased, suggesting that they could effectively retain the activity in the gastrointestinal digestion system. In contrast, the $\mathrm{IC}_{50}$ values of TVFDGELR and LVYIIQGR decreased remarkably $(P<0.05)$. Previous investigations reported that pepsin preferentially cleaves the C-terminal to Phe, Leu and Glu, while pancreatin hydrolyses peptide bonds with aromatic side chains (Tyr, Trp and Phe) at N-terminal or C-terminal. ${ }^{21}$ The peptide LVYIIQGR can be split into LVY and IIQGR by pancreatin, while TVFDGELR can be split into TVF and DGELR. The antioxidant activity of split peptide TVF and LVY that contained F or Y at C-terminal was expected to increase after digestion. ${ }^{19}$

\section{Conclusions}

The optimum enzymatic hydrolysis conditions of palm kernel expeller glutelin-1 were as follows: using pepsin at 
a concentration of $2 \mathrm{~g} / 100 \mathrm{~g}$, hydrolysis time of $4 \mathrm{~h}$, temperature $37{ }^{\circ} \mathrm{C}$ and $\mathrm{pH}$ 2.0. After ultrafiltration, Sephadex G-15 gel chromatography and RP-HPLC, four peptides, TVFDGELR (935.5 Da), ADVFNPR (818.7 Da), CAGVSAIR (832.4 Da) and LVYIIQGR (819.4 Da), were identified from the PKEG-1H. LVYIIQGR showed the highest antioxidant activity $\left(12.85 \mu \mathrm{g} \mathrm{mL}{ }^{-1}\right)$ and CAGVSAIR and ADVFNPR exhibited good stability in gastrointestinal digestion system, indicating their potential usage in health-foods.

\section{Conflicts of interest}

The authors declare that they have no competing interests.

\section{Acknowledgements}

This work was supported by the key research project of Hainan province (No. ZDYF2017061) and the project supported by the National Natural Science Foundation of China (31771858) .

\section{References}

1 B. J. Bhuyan and G. Mugesh, Synthesis, characterization and antioxidant activity of angiotensin I converting enzyme inhibitors, Org. Biomol. Chem., 2011, 9, 1356-1365.

2 S. Y. Dong, M. Y. Zeng, D. F. Wang, Z. Y. Liu, Y. H. Zhao and H. C. Yang, Antioxidant and biochemical properties of protein hydrolysates prepared from Silver carp (Hypophthalmichthys molitrix), Food Chem., 2008, 107, 1483-1493.

3 N. Chen, H. M. Yang, Y. Sun, J. Niu and S. Y. Liu, Purification and identification of antioxidant peptides from walnut (Juglans regia L.) protein hydrolysates, Peptides, 2012, 38, 344-349.

4 L. Wattanasiritham, C. Theerakulkait, S. Wickramasekara, C. S. Maier and J. F. Stevens, Isolation and identification of antioxidant peptides from enzymatically hydrolyzed rice bran protein, Food Chem., 2016, 192, 156-162.

5 M. Zhang, T. H. Mu and M. J. Sun, Purification and identification of antioxidant peptides from sweet potato protein hydrolysates by Alcalase, J. Funct. Foods, 2014, 7, 191-200.

6 Y. F. Zhang, X. Duan and Y. L. Zhuang, Purification and characterization of novel antioxidant peptides from enzymatic hydrolysates of tilapia (Oreochromis niloticus) skin gelatin, Peptides, 2012, 38, 13-21.

7 A. G. P. Samaranayaka and E. C. Y. Li-Chan, Food-derived peptidic antioxidants: a review of their production, assessment, and potential applications, J. Funct. Foods, 2011, 3, 229-254.

8 A. R. Alimon, The nutritive value of palm kernel cake for animal feed, Palm Oil Development, 2010, 40, 12-14.

9 K. L. Chee, H. K. Ling and M. K. Ayob, Optimization of trypsinassisted extraction, physicochemical characterization nutritional qualities and functionalities of palm kernel cake protein, LWT-Food Sci. Technol., 2012, 46, 419-427.

10 Y. J. Zheng, Y. Li, Y. L. Zhang, R. G. Zhang, Q. A. Zhang, Y. F. Zhang and S. L. Zhao, Fractionation, Physicochemical Properties, Nutritional Value, Antioxidant Activity and ACE
Inhibition of Palm Kernel Expeller Protein, RSC Adv., 2015, 5, 12613-12623.

11 Y. N. Tan, M. K. Ayob and W. A. W. Yaacob, Purification and characterisation of antibacterial peptide-containing compound derived from palm kernel cake, Food Chem., 2013, 136, 279-284.

12 A. Tapal, G. E. Vegarud, A. Sreedhara, P. Hegde, S. Inamdarc and P. K. Tiku, In vitro human gastro-intestinal enzyme digestibility of globulin isolate from oil palm (Elaeis guineensis var. tenera) kernel meal and the bioactivity of the digest, RSC Adv., 2016, 6, 20219-20229.

13 Y. J. Zheng, Y. Li, Y. L. Zhang, X. H. Ruan and R. G. Zhang, Purification, characterization, synthesis, in vitro ACE inhibition and in vivo antihypertensive activity of bioactive peptides derived from oil palm kernel glutelin-2 hydrolysates, J. Funct. Foods, 2017, 28, 48-58.

14 K. Kwon, K. H. Park and K. C. Rhee, Fractionation and characterization of proteins from coconut (cocos nucifera L.), J. Agric. Food Chem., 1996, 44(7), 1741-1745.

15 MPOB TOPOMPOB, Production of Palm Kernel Cake 2013, The Official Portal of Malaysian Palm Oil Board Malaysia.

$16 \mathrm{~J}$. Adler-Nissen, Determination of the degree of hydrolysis of food protein hydrolysates by trinitrobenzenesulfonic acid, $J$. Agric. Food Chem., 1979, 27, 1256-1262.

17 J. Y. Qiao, H. H. Lin, S. Qian, Q. J. Zheng and W. Xia, Isolation, identification and synthesis of four novel antioxidant peptides from rice residue protein hydrolyzed by multiple proteases, Food Chem., 2015, 179, 290-295.

18 R. Joshi, S. Sood, P. Dogra and M. Mehendru, In vitro cytotoxicity, antimicrobial, and metal-chelating activity of triterpene saponins from tea seed grown in Kangra valley, India, Med. Chem. Res., 2015, 22, 4030-4038.

19 T. Tavares, M. D. Contreras, M. Amorim, M. Pintado, I. Recio and F. X. Malcata, Novel whey-derived peptides with inhibitory effect against angiotensin-converting enzyme: in vitro effect and stability to gastrointestinal enzymes, Peptides, 2011, 32, 1013-1019.

20 F. Shahidi and Y. Zhong, Novel antioxidants in food quality preservation and health promotion, Eur. J. Lipid Sci. Technol., 2010, 112, 930-940.

21 B. H. Sarmadi and A. Ismail, Antioxidative peptides from food proteins: a review, Peptides, 2010, 31, 1949-1956.

22 Q. J. Yan, L. H. Huang, Q. Sun, Z. Q. Jiang and X. Wu, Isolation, identification and synthesis of four novel antioxidant peptides from rice residue protein hydrolyzed by multiple proteases, Food Chem., 2015, 179, 290-295.

23 A. Alemán, B. Giménez, E. Pérez-Santin, M. C. GómezGuillén and P. Montero, Contribution of Leu and Hyp residues to antioxidant and ACE-inhibitory activities of peptide sequences isolated from squid gelatin hydrolysate, Food Chem., 2011, 125, 334-341.

24 H. C. Wu, H. M. Chen and C. Y. Shiau, Free amino acids and peptides as related to antioxidant properties in protein hydrolysates of mackerel (Scomber austriasicus), Food Res. Int., 2003, 36, 949-957. 